Armagh. The Primate gave as an endowment of the Observatory twenty acres of land close to Armagh, on which the Observatory is built, and the estate of Derrynaught, which he had bought out of his private means. He further provided for the salary of an assistant and the current expenses of the Observatory. The power of nominating and appointing the astronomer is reserved for the Archbishop of Armagh and Primate of all Ireland for the time being. The first astronomer of the Observatory was the Rer. Dr. J. A. Hamilton, who was succeeded in 1815 by the Rev. W. Davenport, and then, in 1823, by the Rev. T. R. Robinson, who held the post until his death in 1882-a period of more than fifty-eight years. The anemometer which bears Dr. Robinson's name was first put up on the roof of the Observatory in 1846, but meteorological observations had been commenced thirteen years earlier. Dr. J. L. E. Dreyer succeeded Dr. Robinson in 1882, and the next director appointed was Mr. J. A. Hardcastle, who, however, died in 1917 without having actually taken up the post. The Rev. W. F. A. Ellison became director in 1918 and occupied that position until his death at the end of last year.

\section{Royal Institution: Annual Meeting}

THE annual meeting of the members of the Royal Institution was held on Saturday, May 1. In the unavoidable absence of the president, the Right Hon. Lord Eustace Percy, the chair was taken by Major Charles E. S. Phillips, secretary and vice-president. In submitting the annual report of the Visitors to the meeting, the chairman referred to the satisfactory state of the membership, which has increased steadily in recent years, and which stands now, including honorary as well as full members and associate subscribers, at 1,055. The reconstruction of the Library and other rooms, which the Managers were forced to undertake when a large part of the building was found to be in an alarming state of disrepair, was completed in October. This work, which the accounts show had cost nearly $£ 16,000$ at the end of the year, and included the construction of a large new laboratory, has added greatly to the beauty and convenience of the house. Owing to the withdrawal of the direct current mains in Albemarle Street and neighbourhood, it has been necessary for the Institution to provide its own equipment for the supply of direct electric current. A large storage battery and two mercury arc rectifiers, supplied from the A.C. mains, have been installed. The output from the rectifiers has been specially smoothed, and is found to be sufficiently free from ripple for most experimental purposes. The battery is used for are lanterns in the lecture theatre.

THE expenditure on these and other purposes has been largely met from the munificent bequest of the late Mr. Harry Brown, which, it is now reported, has amounted to more than $£ 29,000$. No. 19 Albemarle Street, adjoining the Institution's premises, recently purchased, has now been fully occupied. The two top floors are used for library and museum extension, and the lower floors have been let off for the present, producing income which is being devoted to research purposes. The accounts of the Davy Faraday Re. search Laboratory, in which the Institution's research expenditure is accounted for, show a deficit of nearly $£ 2,000$ on the year's working. The chairman was able to announce a generous Coronation year gift by the honorary secretary of the Laboratory, Sir Robert Mond, of a sum of money sufficient to meet the deficit. The following were elected to the various offices: President: The Right Hon. Lord Eustace Percy. Treasurer: Sir Robert Robertson. Secretary. Major Charles E. S. Phillips. Managers-Sir John Cadman, Sir James Crichton-Browne, Dr. Cecil H. Desch, Sir James Devonshire, Prof. A. C. G. Egerton, Lord Falmouth, Mr. J. S. Highfield, Mr. Arthur Jaffe, Sir William Larke, Mr. V. Warren Low, Sir Murdoch MacDonald, Mr. C. C. Paterson, Prof. J. C. Philip, Sir Thomas Purves and Admiral C. V. Usborne. Visitors-Mr. C. Cuthbertson, Prof. C. L. Fortesque, Dr. J. J. Fox, Captain A. C. Goolden, Prof. H. Hartridge, Mr. Emil Hatschek, Prof. F. L. Hopwood, Dr. R. Lessing, Mr. A. H. Levy, Mr. F. I. G. Rawlins, Mr. Russell J. Reynolds, Prof. H. R. Robinson, Dr. G. Shearer, Major W. S. Tucker and Colonel W. A. Vignoles.

\section{Shakespeare's Universe}

For his Friday evening discourse before the Royal Institution on April 30, Prof. J. Dover Wilson dis. cussed "Shakespeare's Universe". To understand Shakespeare, he said, one must understand his universe-a very different one from that of Newton, and still more from that of Einstein. In his day the ideas of Copernicus and Galileo were just beginning to penetrate to the consciousness of the ordinary man, and did not become really influential until after the middle of the seventeenth century. Shake. speare lived in a universe which, first described by Ptolemæus of Alexandria in the second century A.D., held sway over men's minds throughout the Middle Ages and had thus served humanity for fifteen hundred years. The best picture of this universe in our literature is to be found in "Paradise Lost", for though Milton understood the new astronomy and actually refers in his poem to Galileo, whom he had met in Italy, he made use of the old scheme of ten concentric spheres with the earth at the centre. As the spheres revolved at different rates and with their own peculiar motions on one another, they made music which was known as "the music of the spheres"; the sound was inaudible to mortal ears. Shakespeare's description of this astral musical box is well-known. Thus the universe was a 'harmony' ; and harmony is the master-key of Shakespeare's thinking, whether upon the world at large, upon human society, or upon man himself, man the microcosm which reflected the macrocosm in little.

Music meant a great deal to Shakespeare. It had medicinal properties to which he often refers. Moreover, the man of harmony would be at once fond of music and a good citizen, because human 